\title{
Article
}

\section{The gains and losses of face in ongoing intercultural interaction: A case study of Chinese participant perspectives}

Wang, Jiayi and Spencer-Oatey, Helen

Available at http://clok.uclan.ac.uk/13622/

Wang, Jiayi ORCID: 0000-0003-2720-8218 and Spencer-Oatey, Helen (2015) The gains and losses of face in ongoing intercultural interaction: A case study of Chinese participant perspectives. Journal of Pragmatics, 89 . pp. 50-65. ISSN 0378-2166

It is advisable to refer to the publisher's version if you intend to cite from the work. http://dx.doi.org/10.1016/j.pragma.2015.09.007

For more information about UCLan's research in this area go to http://www.uclan.ac.uk/researchgroups/ and search for < name of research Group>.

For information about Research generally at UCLan please go to http://www.uclan.ac.uk/research/

All outputs in CLoK are protected by Intellectual Property Rights law, including Copyright law. Copyright, IPR and Moral Rights for the works on this site are retained by the individual authors and/or other copyright owners. Terms and conditions for use of this material are defined in the policies page.

\section{CLoK}

Central Lancashire online Knowledge www.clok.uclan.ac.uk

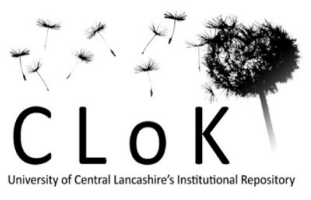




\title{
The gains and losses of face in ongoing intercultural interaction: A case study of Chinese participant perspectives
}

\author{
Jiayi Wang and Helen Spencer-Oatey
}

\author{
Published in Journal of Pragmatics, November 2015, Vol. 85, pp.50-65.
}

\begin{abstract}
Given the small number of existing studies of face in intercultural settings and the increasing attention given to participant perspectives in face research, this paper explores the gains and losses of face as perceived by Chinese government officials during a three-week delegation visit to the United States of America. These perspectives were obtained from the group's spontaneous discussions during regular evening meetings when they reflected on the day's events. Several key features emerged from the discussions. Firstly, face enhancement was a primary goal for the visit - enhancement of their own face as a delegation, of the face of the Ministry they belonged to, as well as the face of their American hosts. Secondly, the delegates attempted to manage these face goals strategically. Thirdly, they spoke of face as a volatile image that could rise and fall sharply and yet endured across incidents, days and weeks. The paper reports on and discusses these participant perspectives in the light of recent theorizing on face.
\end{abstract}

\section{Keywords:}

Face dynamics; face management; face enhancement; participant perspectives; first/second order distinction; longitudinal case study.

\section{Highlights}

- Delegation members talked spontaneously about face as they reflected on days' events;

- They placed face enhancement as their primary goal;

- They aimed to manage it strategically;

- They spoke of face as a volatile image that endured over interactions and time;

- These perspectives are discussed in relation to recent theorizing on face.

\section{Introduction}

Research on face has a long and multidisciplinary history, yet there have been only a few studies (e.g. Grainger, Mills and Sibanda, 2010; Haugh and Watanabe, 2009; Ting-Toomey, 2009; Ting-Toomey and Kurogi, 1998) investigating it in intercultural settings, especially from a longitudinal point of view. This paper explores the subjective experiences of Chinese officials during a three-week delegation visit to the United States of America, focusing on their perceptions of face that they discussed spontaneously during private evening meetings. Face is 
widely regarded as a core concept for analyzing interpersonal relations, and in Brown and Levinson's (1978/1987) model it was used as the main explanatory concept for politeness. More recently, while acknowledging the central role face plays in (im)politeness research, a growing number of researchers (e.g. Arundale, 2013; Haugh, 2009, 2013; Haugh and BargielaChiappini, 2010; Spencer-Oatey, 2007; Watts, 2005) have been calling for face to be studied as a research area of its own and theorized independently of politeness, in an attempt to gain (new) insights into these (old) debates (Bargiela-Chiappini, 2003). Our study offers a unique opportunity to take this agenda forward as our data is special in several ways: the type of data collected is rarely accessible, it is longitudinal in nature, and entails the participants talking explicitly about face themselves. This contrasts with the more common situation in which face is analyzed in single encounters and it is the analysts rather than the participants who identify issues of face. In our view, facework is "not a one-shot exchange" (Lim, 2009:265), and in this paper we demonstrate this point by exploring how Chinese officials experienced gains and losses of face as they interacted with their American hosts over a three-week period.

We begin by considering some current gaps and dilemmas in our understanding of face and then describe the data collection and analysis procedures we used in our study. We report the findings by presenting the Chinese participants' spontaneous comments on face, taking a chronological approach so that participants' real time sense of ups and downs can emerge. The paper ends by relating the findings to current debates and controversies.

\section{Literature review}

Historically, the term 'face' has travelled across languages, cultures and regions. The figurative meaning of face originates from Chinese culture (Hsun, 1960; Lin, 1935) and can be traced back to as early as the $4^{\text {th }}$ century BC $(\mathrm{Hu}, 1944)$. In the $19^{\text {th }}$ century British missionaries living in China brought it from Chinese to English (Haugh and Hinze, 2003; Ho, 1976), introducing into English the phrase "to lose face". Later, the opposite meaning, 'to save face', was coined in English and was reimported back into modern Chinese discourse (St. André, 2013).

In academic research, the concept of face has spawned a wealth of explanations and applications (Haugh and Hinze, 2003) and transcended cultural boundaries (Haugh and Bargiela-Chiappini, 2010). For example, the renowned American sociologist Erving Goffman (1959, 1967) conceptualized it as the foundation of the organization of interpersonal encounters, elevating it to "the traffic rules of social interaction" (1967:12). Later, the linguists Brown and Levinson (1978/1987) took it as the core of the language universal of politeness. Brown and Levinson seem to view face more as a personal possession, while Goffman (1959, 1967) seems to place more emphasis on its evaluative nature, highlighting evaluations made by others. Both these seminal works offer useful insights, drawing attention to different analytic perspectives. They have helped stimulate multidisciplinary research on face, and are still having a far-reaching impact (Bargiela-Chiappini, 2003; Grainger, Mills, and Sibanda, 2010; Hinze, 2012; Spencer-Oatey, 2007). However, while face has undeniably become increasingly central in research on social interaction, the academic debate over its conceptualization continues and there are aspects that are still under-researched. We review some of these issues below. 


\subsection{The dynamics of face}

An impressive body of research has focused on the consequences of face-related behavior. According to Goffman (1967:9), face can be "lost, saved, given and gained”, and similarly, Brown and Levinson (1987:61) argue that it can be "lost, maintained, or enhanced, and must be constantly attended to in interaction.”

A major focus of face research has been on saving face, especially in the context of politeness research. Saving face involves avoiding or reducing face threats, and many studies (e.g. Bravo, 2008; Brown and Levinson, 1987; Chen, 1993; Chen, He, and Hu, 2013; Nwoye, 1992; Ruhi and Işık-Güler, 2007) have enriched our understanding of the verbal and behavioral strategies for managing this. Losing face was traditionally associated with failure to engage in facesaving behavior. However, since Culpeper's (1996) influential work on impoliteness, research on face attack and face loss has been burgeoning especially over the past few years (Bousfield, 2008; Bousfield and Locher, 2008; Chang and Haugh, 2011; Culpeper, 1996, 2008, 2011, 2012; Culpeper, Bousfield, and Wichmann, 2003; Culpeper, Marti, Mei, Nevala, and Schauer, 2010; Haugh, 2010).

Compared with saving and losing face, gaining face or face enhancement, whether oriented towards self or other, has been particularly under-conceptualized and under-researched. While Goffman (1967) and Brown and Levinson (1987) explore face saving in detail, they only mention face enhancement/giving in passing. The same is true of more recent works (e.g. Eelen, 2001; Domenici \& Littlejohn, 2006; Kádár and Haugh, 2013).There are several possible reasons for this lack of attention. First, an unpublished study by Ting-Toomey (personal communication cited by Morisaki and Gudykunst, 1994:86) found that people in the United States of America had difficulty "conceptualizing giving face to another person”, so similar difficulties might exist for conceptualizing the natural result of giving face, i.e. gaining face. Second, gaining face usually has less serious consequences than losing face.

Nevertheless, sporadic studies (Hernández-Flores, 2004; Ho, 1976; Seligman, 1999) have identified this 'face giving' behavior. For example, Hernández-Flores has observed face enhancement in Spanish conversations between friends and family (2004), and in TV debates (2008). She has made a further distinction between self-face enhancement, or 'self-facework' in her words, which focuses on "one's own face without directly affecting the addressee's face" (2008:694-695), and face enhancement involving "achieving an 'ideal' balance between the addressee's face and the speaker's face by confirming their own face wants" (2008:693). She argues that the former is not politeness in a strict sense, while the latter is, and that politeness is a type of facework. For example, if you ask a colleague to read your draft article, you might start by enhancing his/her face through using compliments (e.g. "I know you're an expert...”) as a means of mitigating the face threat of your request. In this case, face enhancement is a politeness strategy for reducing face threat. Similarly, as Spencer-Oatey (2008: 19) argues, impositive speech acts can be face enhancing as well as face threatening, in that while we may feel imposed on by a request, we may also "feel pleased or even honoured if someone asks us for help, feeling that it shows trust in our abilities and/or acceptance as a close friend.” In line with this, Hernández-Flores (2008: 94) points out that face enhancement does not necessarily "depend on the presence of threats to face, but has the purpose of confirming or enhancing the speakers' face”. She $(2004,2008)$ reports that such behavior was frequently observed in her data collected in an Iberian Spanish community. For instance, she gives the following example which took place during a meal where a couple, Pili and Gabriel, had invited their neighbors Celia and Rosalía to dinner. The husband, Gabriel, asked his wife Pili for more food ("Pili, a 
little piece more of, chicken"). This request and subsequent responses from Pili and Celia show that "no threat to face is seen" (Hernández-Flores, 2004:277) in this context. Pili, for instance, received the request positively by saying that her husband likes eating the food she cooks, while their neighbor Celia continued the face-enhancement work by praising the food prepared by the hostess. Hernández-Flores's analysis of this example displays face enhancement without the presence of a face threat. Similarly, Gao (2009:183) refers to 'giving face' as one of the most practiced skills in Chinese social interaction, and she maintains that through giving face, “others' personal and social identities are maintained, affirmed, and/or promoted." However, since face threat/enhancement is a subjective perception, whether the other person necessarily interprets an act as face enhancing or as face threatening or both cannot always be controlled. It is possible that different participants may interpret a given act in different ways. This leads us to another issue: the strategic management of face and the issue of intentionality.

\subsection{The strategic management of face}

The strategic management of face raises the issue of intentionality (see Culpeper, 2011:48-49 for a review). Classic studies (Brown and Levinson, 1987; Leech, 1983) highlight the speaker's intention towards another in performing a face-threatening speech act. For example, Goffman (1967) identified three kinds of intentionality associated with face threatening acts. First, a person wants to hurt the others' face on purpose, and is malicious in intent. This has been studied occasionally with various labels, such as face attack (Culpeper, 1996, 2005, 2011; Culpeper et al., 2003; Tracy, 2008). Second, a person unwittingly causes damage to the others' face by accident. This may or may not trigger a repair or a corrective process. It sometimes could be seen as a social faux pas. Third, a person is fully aware of the potential face threat of his/her behavior but he/she has no choice but to perform it due to various reasons such as interactional goals (Spencer-Oatey, 2008) and responsibility. Before doing such a face threatening act (FTA), he/she may “design” his/her action to minimize the damage.

Brown and Levinson (1987) aimed at describing how people rationally 'calculate' the weightiness of an FTA and choose a strategy corresponding to the perceived level of face threat. They emphasize the face-threatening aspect of all acts, and so much of the discussion in the literature on the strategic aspect of face has largely taken a face-threatening perspective. Yet, despite the weaknesses of their model, their thinking can illuminate the importance of people's intentions (Culpeper, 2008, 2011; Terkourafi, 2007), even though, in our view, the strategic management of face should by no means be limited to managing face threats. A broader perspective is taken by Spencer-Oatey (2008), who proposes that people can hold four different types of rapport orientation:

1. Rapport enhancement orientation: a desire to strengthen or enhance harmonious relations between the interlocutors;

2. Rapport maintenance orientation: a desire to maintain or protect harmonious relations between the interlocutors;

3. Rapport neglect orientation: a lack of concern or interest in the quality of relations between the interlocutors (perhaps because of a focus on self);

4. Rapport challenge orientation: a desire to challenge or impair harmonious relations between the interlocutors.

Spencer-Oatey, 2008:32

We suggest that people may similarly hold different face orientations and that there is a particular need to explore that of face enhancement as it has so rarely been investigated. In this 
study, we take a bottom-up approach and seek insights into ways in which the Chinese officials aimed to manage face strategically in their intercultural interactions.

\subsection{Face as emergent and/or durative}

Most face studies have investigated moments of face threat or face loss within a single encounter. This may be partly attributed to a conceptual focus on transiency; for example, Goffman's $(1959,1967)$ dramaturgical theorization of face focuses on face as a temporary mask on loan to an individual for a particular encounter. In a similar vein, Arundale's (2006, 2010, 2013) Face Co-constituting Theory concentrates on face as emergent and co-constituted in a single face-to-face interaction. Such studies have offered important insights into facework as a process of becoming, and they have illustrated the ways in which face is constantly being managed, negotiated and co-constructed in interaction. However, we would question whether that is comprehensive enough an understanding of face. Goffman (1967: 31, emphasis added) also maintains that face is "an image pieced together from the expressive implications of the full flow of events", and Lim (2009: 265, emphasis added) claims that "facework is not a oneshot exchange”. Ho $(1976,1994)$ points out that for Chinese, people can take face with them wherever they go and a number of other researchers (e.g. Sifianou, 2011, 2013; Spencer-Oatey, 2007) have made similar observations. So we would argue that face can be not only discursively constructed, but also an enduring phenomenon, with its development over a period of time, beyond a single interaction, also meriting attention. This is in line with Garcés-Conejos Blitvich's (2013) assertion that we need more longitudinal studies that can yield insights into face emergence and maintenance over time.

If face is enduring (though not static), this raises the question as to whether it can be possessed and if so, by whom (e.g. Sifianou, 2011, 2013). Goffman (1967) and Brown and Levinson (1987) treat it as an individual phenomenon, but as several authors have pointed out (e.g. He and Zhang, 2011; Ho, 1976; Nwoye, 1992; Spencer-Oatey and Xing, 2008), it can also be associated with groups. Very little research has explored this perspective.

\section{$2.4 \quad$ Face, Identity and Image}

A number of scholars (e.g. Arundale, 2010; Garcés-Conejos Blitvich, 2013; Spencer-Oatey, 2007) have recently started discussing the interrelationships between face and identity. Traditionally these concepts have been studied in different fields (e.g. pragmatics and psychology respectively), with relatively little intersection between them. However, it is now more widely acknowledged that the distinction between them is fuzzy, and Garcés-Conejos Blitvich (2013: 8) actually argues that "it is not possible to conceptualize face without taking identity into consideration.”

Less frequently discussed is the interconnection between face and image. Brown and Levinson (1978/1987) define face in terms of self-image, so this raises the question as to whether 'face' and 'image' are identical in meaning. There are clearly interconnections, but in our view they are not quite the same, in that 'face' draws attention to issues such as reputation and dignity while 'image' refers more generally to the concept of picture or impression.

\section{$2.5 \quad$ Researching Face}

Haugh (2009) points out that a crucial issue in face research is how we can determine whether or not face or facework is a relevant analytic concept for a particular interaction. He argues for the importance of incorporating the participants' perspective: 
We, as analysts, therefore need to show that face is indeed 'demonstrably relevant to the participants' (Schegloff, 1991: 50). [...] In focusing on the 'participants' analyses of one another's verbal conduct - on the interpretations, understandings, and analyses that participants themselves make, as displayed in the details of what they say' (Drew, 1995: 70, original italics), then, the analyst can establish that (1) the interaction does involve the participants making such evaluations, and (2) these evaluations are procedurally consequential for the flow of the discourse.

Haugh 2009:10

He goes on to point out that one possible way of learning about the participants' perspective is to consult them, but that this inevitably creates another text, only this time in interaction with the analyst.

We firmly agree with Haugh and others such as Eelen (2001) who take a similar line. We believe that it is extremely important to take a participant perspective, and in fact our study aims at revealing first-order participant perspectives on face (Haugh, 2012). But we go a step further. On the one hand, we argue that these judgments are not only "procedurally consequential for the flow of the discourse” (Haugh 2009:10), but are also strategically consequential for the planning of future behavior. Moreover, as we explain in our methodology section, finding out about the participants' perspectives does not inevitably mean interaction with the analyst. We were fortunate enough to obtain regular, spontaneous reflections by the Chinese delegates on their interactions that day with their American hosts. It certainly created another text, but it was a participant-generated text, not a researcher-induced text, and in this sense relatively unique. It is also unusual in that, as explained below, face was discussed explicitly and spontaneously by the participants, offering a wonderful opportunity to garner participant perspectives and insights on the concept.

\section{Methodology}

As mentioned above, the aim of our study was to explore the subjective experiences of Chinese officials during a three-week delegation visit to the United States of America. This kind of professional interaction, which involved government officials from both the USA and China, has rarely been studied before, not least because it is so difficult to gain access to. We took an emergent approach, so our initial research question was very broad: what experiences during their trip did the Chinese delegates notice as being professionally significant in some way. We focused on the Chinese participants' perspectives, partly because that was more feasible given the practicalities of the trip and partly because it is less common to hear Chinese participants' voices commenting on interactions with people of other nationalities. As explained below, we collected a range of data and then narrowed our focus. Through initial analyses, we identified 'face' as a key concern and so this paper focuses on that issue.

\subsection{Data collection}

The field researcher collected data for a single case - a three-week official delegation trip to the USA. All the Chinese delegation members had prior experience of interacting with nonChinese professionals and all had previously been abroad for work purposes. We selected the delegation trip as a revelatory case because it offered us unique access to the Chinese officials' natural spontaneous interpretations of their intercultural interactions. Every evening of each working day, the head of the delegation convened a group meeting to reflect on what had happened during the day and to make plans for the following day. Although most senior 
Chinese officials of international delegations hold reflection meetings, it is rare for a group to hold one every day during their stay overseas. This trip then offered us a remarkable opportunity to examine how the Chinese participants interpreted their interactions with their American hosts and to follow how they perceived the gains and losses of their face during the course of their visit.

We took an ethnographic-type approach to data collection. From the beginning to the end of the trip, the field researcher was involved in the delegation's 'daily lives' (Hammersley and Atkinson, 2007:3), watching and recording what happened, listening to what was said both in front of the Americans and behind their backs, asking questions through informal interviews and by collecting documents. In fact, the field researcher was "gathering whatever data" were available to "throw light on the issues that are the emerging focus of inquiry" (Hammersley and Atkinson, 2007:3). Similar to other ethnographic-type research, a wide range of sources of data were collected in a relatively "unstructured" manner and the study did not follow a "fixed and detailed research design specified at the start” (Hammersley and Atkinson, 2007:3).

\subsubsection{Participants}

The delegation was made up of twenty senior Chinese officials from a government Ministry, along with the field researcher. The officials had worked with each other for a long time and knew each other well. For confidentiality reasons, we anonymized all the Chinese participants' names as well as their Ministry. Apart from the head of the delegation and the deputy head of the delegation who are referred to by their titles (HOD and DHOD respectively), we gave each of the delegates a code $\mathrm{DN}$ ( $\mathrm{D}=$ delegate; $\mathrm{N}=$ =number). The American participants were also given aliases. All participants gave permission for the daytime meetings to be video recorded, for full notes to be taken at the evening meetings, and they also agreed to be interviewed.

\subsubsection{Video and audio recordings}

A total of twenty-one out of twenty-six intercultural events, including both the welcome lunch banquets and meetings, were video/audio-recorded. Overall around 20 hours of video recordings amounting to 78.6GB and 2 hours of audio recordings were collected.

\subsubsection{Evening meeting notes}

The head of the delegation (HOD) convened an evening reflection meeting every working day and the field researcher took a full record, using interpreter's shorthand. There were twelve evening meetings (EMs) averaging twenty minutes in length. Over 50 pages of shorthand notes were transcribed and translated into a record of more than 15,000 words. All twenty members of the delegation, plus the field researcher, took part in all the evening meetings.

The evening meetings were always held in the HOD's spacious hotel suite. It is interesting to note that the location helped significantly to lighten the atmosphere of the meetings. Even though the suites were usually very spacious, there were not enough proper seats for everyone. After all, a suite is not designed to accommodate twenty-one people for a meeting. Therefore, some delegates sat on a sofa, some in chairs, and others on the bed. This 'cozy' room layout, unlike that of a roundtable on formal occasions, seemed to facilitate the flow of discussions. In addition, there was no time limit or agenda. When all the issues of concern raised on that day had been covered, the HOD would naturally conclude it. During the meeting, any delegate could raise any issue and make any comments. Throughout the trip, the evening meetings were kept as a routine and they were viewed as the primary and most effective channel of internal 
communication. The delegation reached group consensus and made most of their decisions there.

\subsubsection{Interviews}

In order to obtain a better understanding of the trip, the field researcher conducted 41 postevent and post-trip interviews ${ }^{1}$ in Chinese with these 20 delegates, and shorthand records were taken. First, the twenty-three post-event interviews were open-ended and led by a simple question: “What impressed you the most today?” When time and space permitted, face-to-face interviews were conducted with one to three delegates, individually, after an intercultural meeting or after a day of meetings. These interviews usually took place in the field researcher's hotel room at noon or in the evenings. Additionally, eighteen one-to-one post-trip 'narrative interviews' (Hopf, 2004) were held over the telephone after the delegation returned to China. The field researcher asked a few questions including "What were the biggest challenges to intercultural meetings?" and "How to overcome them?" as well as the simple elicitor "What impressed you the most in the trip?”

\subsubsection{Role of the field researcher}

It should be noted that the field researcher played a dual role throughout the trip. On the one hand, she was working as an official interpreter and administrator for the delegation, and this enabled her to attend all events as a true participant, accessing the delegation's spontaneous interpretations and their reactions and responses to the situations as they occurred throughout the visit. In other words, she did not need to rely on researcher-initiated interviews, although she also conducted some. On the other hand, she was a field researcher. While gathering the data, she informed the Chinese and American participants that she was doing research on intercultural communication and that the data would be used for research purposes. Permissions were then given. We do not deny that the dual roles may have had an impact, particularly on the American participants. However, our focus was on Chinese perspectives, and since the field researcher was well known to the delegation members, they treated her as a true insider, not showing any reservations over their comments.

\subsection{Data analysis}

As explained above, the aim of our study was to explore the delegates' perceptions of their interactions with their American hosts. Since we wanted to focus on the issues that were important to the participants, we started by examining the evening meeting (EM) data where the Chinese delegates spontaneously commented on the things that had happened which were particularly salient to them. We decided to use a quantitative approach to help with this. With the aid of the corpus analysis tool, AntCon, which was suitable for analyzing data in Chinese, we carried out word frequency analyses of the EM texts. Interestingly, and somewhat to our surprise, guanxi (relations), mianzi and $\operatorname{lian}^{2}$ (face) and xingxiang (image) emerged as the most frequent words. ${ }^{3}$ Although these terms often co-occurred and are often closely interconnected,

\footnotetext{
${ }^{1}$ These open-ended interviews ranged from ten to thirty minutes. While the interviews were generally informal and free flowing, a list of the key post-trip interview questions is included in the appendix.

${ }^{2}$ Given the fact that mianzi and lian were used interchangeably by the participants and that this paper focuses on the conceptualization of face overall, we took them both as face labels.

${ }^{3}$ We used the software package ICTCLAS to segment the Chinese EM texts and then the corpus analysis tool AntCon to generate wordlists and concordances. We set up three criteria for dropping certain terms in running frequency analysis: a) function words such as prepositions and particles, b) common vocabulary that did not have a meaningful impact on our current research objective such as “morning” and "give”, and c) widely used terminologies in the subject area of $\mathrm{X}$ which must be anonymised. All the stop words were screened through
} 
in this paper, we focus primarily on the delegates' comments about face. Sometimes the delegates seemed to use mianzi/lian (face) and xingxiang (image) almost interchangeably (e.g. see Data Extract 1 below), indicating the close connections between the two, and lending support to the general conceptualization of face as a positive social image (e.g. Brown \& Levinson, 1987; Goffman, 1967; Spencer-Oatey, 2008). However, the two notions are not identical. For example, in our data, a senior American official talked about his grandchildren at a formal meeting with the Chinese delegates, the first time they met. Mentioning his family breached the Chinese officials' expectations of a senior official (who should not mention family on such formal occasions) and they talked about this at their evening meeting. It is clear from their discussion that his comments affected their image (i.e. their impression) of him, but that it did not affect their perceptions of his face. So we regard, face and image as two interrelated yet distinct concepts and in this study, which primarily focuses on face, we picked out all the occurrences of face (mianzi/lian). There were 39 instances altogether, as shown in Table 1.

Table 1: Mentions of face, image and guanxi at the evening meetings

\begin{tabular}{|c|c|c|c|}
\hline $\begin{array}{l}\text { Evening } \\
\text { meeting }\end{array}$ & Mentions of face & Mentions of image & $\begin{array}{c}\text { Mentions of guanxi } \\
\text { (relation/relationship) }\end{array}$ \\
\hline \multicolumn{4}{|c|}{ Week 1} \\
\hline 1 & 10 & 10 & 6 \\
\hline 2 & 2 & 2 & 1 \\
\hline 3 & 0 & 0 & 4 \\
\hline 4 & 4 & 0 & 5 \\
\hline 5 & 3 & 0 & 1 \\
\hline Subtotal & 19 & 12 & 17 \\
\hline \multicolumn{4}{|c|}{ Week 2} \\
\hline 6 & 5 & 2 & 3 \\
\hline 7 & 1 & 0 & 0 \\
\hline 8 & 2 & 0 & 4 \\
\hline 9 & 2 & 0 & 1 \\
\hline 10 & 6 & 0 & 2 \\
\hline Subtotal & 16 & 2 & 10 \\
\hline \multicolumn{4}{|c|}{ Week 3} \\
\hline 11 & 0 & 2 & 4 \\
\hline 12 & 4 & 1 & 10 \\
\hline Subtotal & 4 & 3 & 14 \\
\hline Total & 39 & 17 & 41 \\
\hline
\end{tabular}

If the term was used more than once in relation to the same situation, we counted it numerically only once and identified it as one face incident. Thirteen incidents with explicit face labels were extracted. We then went back to the other data sources, such as video recordings of the

concordances to make sure that they were of no interest. As a result, the most frequent words emerged and they included “American side” (x95 mentions), "gift” (x75), "USA” (x72), “guanxi” (x41), "China/Chinese” (x39), “delegation” (x25), “X Ministry/Department” (x25), "meeting” (x22), "lunch banquet” (x19), “official” ([noun] x19), “image” (x17), "government” (x17), “mianzi” (face, x16), "federal” (x15) and "lian” (face, x14). It is noteworthy that Chinese is a non-inflectional language, so, for example, nouns could denote both singular and plural forms. 
official meetings, to examine the incidents in the contexts in which they occurred. All these face episode data were analyzed in chronological order and coded in NVivo.

In selecting these incidents where face was referred to explicitly, we acknowledge that they do not necessarily represent all of the Chinese delegates' perceptions of face-sensitive experiences. There may well have been others that they did not explicitly comment upon, but that may have become apparent from detailed analyses of the discourse data in the video recordings. However, given the volume of that data, and given the challenges of making those interpretations, we decided to focus on the explicit evaluative comments of the Chinese participants. We would argue that these evening meeting comments offer a relatively unique opportunity to gain insights into the delegates' perspectives and interpretations of their ongoing interactions with their American hosts.

\section{Chinese delegates' concerns about Face}

In this section we describe how the Chinese delegates' concerns about face played out during the three-week period. For space reasons, we cannot report all of the face incidents; we just present a selection from across the three-week period. Our rationale for selection was to illustrate the different ways in which the delegates talked about face and the various different facets of face that emerged. We include the Chinese version of our quotations in footnotes so that those who are familiar with Chinese can read them in the original language rather than depending on our translated versions. ${ }^{4}$ (cf. Haugh, 2012)

\subsection{The Start: Face enhancement as the goal}

The importance of face was established from the very start of the trip. In fact, at the delegation's pre-departure meeting, senior ministerial leaders gave clear instructions that the delegation's goal should be to increase the face of both the delegation and the Ministry, and this goal was reiterated by the HOD during their first evening meeting in the US on Day 3:

\section{Data extract 1: EM Comment ${ }^{5}$}

We are here in the US as a delegation, a collective group composed of every member from various organizations (or/and departments) [under the Ministry]. This collective group has its own group image, ${ }^{6}$ i.e. the delegation's face. Our image is made of everyone's. I hope that on the current basis, we can build a better image. In a strict sense, the delegation's face is made of your face. If you don't pay attention to your own face, your personal behavior will affect our collective image, or even our $\mathrm{X}$ Ministry's image. We should not only increase our delegation's face but also our Ministry's face [...]. Every detail has to do with our image. We should be responsible

\footnotetext{
${ }^{4}$ When translating verbatim notes from Chinese into English, we employed the approach of "formal equivalence" (Nida and Taber, 1969), which emphasizes strict adherence to the original text and is oriented towards the source language and culture, whereas "functional equivalence" (Nida and Taber, 1969), also known as "dynamic equivalence”, stresses being natural in the target language and target culture, catering to the target audience. For example, functional equivalence encourages adjustments to the target culture by replacing a culture-specific message in the source text with an equivalent in the target culture. In order to reveal the Chinese officials' internal discussions with fidelity, we retained all the messages in our translation even those that may sound unusual to English readers such as idioms.

${ }^{5}$ In all data extracts, face has been italicised for ease of reference.

${ }^{6}$ As can be seen from this extract, the Chinese officials used face and image interchangeably. The relations between the two concepts have been expounded earlier in Section 3.2 Data analysis.
} 
not only for ourselves but also for our delegation's image. Therefore, throughout our stay in the US, we must constantly enhance our image. ${ }^{7}$

As can been seen, increasing face was an explicit goal for the Chinese officials. Interestingly, the main focus was the face of the delegation, and beyond that the Ministry's face. The HOD did not express any concern for the face of individual delegates, except insofar as the individual member's behavior could affect the face of the group. In other words, one of the main goals of the trip was to enhance the face of the delegation.

\subsection{Week 1: The gains and losses of face}

On their first day of meetings, the Chinese HOD and the American Director exchanged gifts at the welcome banquet at lunchtime. The American Director gave a paperback picture book wrapped in red paper, while the Chinese HOD gave a large wooden box containing five clay figures of Chinese gods of wealth. It was clear that the American gift appeared much less lavish than the Chinese gift, and one might have predicted that this would have been face-threatening to the Chinese (i.e. the Chinese might have felt they were not deemed worthy enough to warrant a more expensive gift). ${ }^{8}$ In fact, however, their reaction was just the opposite as can be seen from their comments in the evening meeting:

\section{Data extract 2: EM Comment}

HOD: $\quad$...today, the gift we gave has added luster to our delegation’s face. ...

DHOD: The gift we gave today was very successful and especially faceenhancing for us. ${ }^{9}$

Their interpretation was explained in more detail by one of the delegates in a post-event interview (PEI):

\section{Data extract 3: PEI comment}

The moment I saw the size of the American gift, I knew that we had won [...] We compare each other's gifts forever and it's like a competition. We have absolutely outdone them [...] It is a very good start [to this trip]. Our gift compared with theirs has earned face for our delegation as a whole. ${ }^{10}$

Clearly the delegates interpreted the gift exchanges from a face perspective and once again it

\footnotetext{
${ }^{7}$ 我们到美国是作为一个代表团, 代表团是由各单位团员组成的一个集体。我们这个集体, 有一个集体 形象, 也就是我们代表团的面子。我们的形象是由每个人组成的, 希望能在现有形象的基础上, 树立更 好的形象。严格来讲, 代表团的面子就是由大家的面子组成的, 如果你不注意自己的面子, 你个人的行 为会影响到我们集体的形象、甚至是我们部的形象。我们不仅要给我们代表团长脸, 也要给我们 $\mathrm{X}$ 部长 脸......每个细节都关系到我们的形象。大家不仅要对自己负责, 也要对代表团的形象负责, 所以在美期 间, 大家要一直不断提升我们的形象。

${ }^{8}$ The Chinese officials always linked gift-giving to face, which echoes the findings of prior research on the close relationship between Chinese face and gift-giving (e.g. Li and Su, 2007; Qian, Razzaque and Kau, 2007; Yan, 1996; Yang, 1994). For example, Qian and colleagues' (2007) study of the Chinese people's gift-giving behavior during the Spring Festival found that face could have a major impact on the importance attached to gift-giving and the amount given.

${ }^{9} \mathrm{HOD}$ : 今天, 我们送的礼物让我们代表团脸上增光.......DHOD: 今天我们送的礼物挺成功的, 特长脸。 10 一看到美方的礼物, 我就知道我们赢了......我们永远都会比较彼此的礼物, 就跟比赛似得, 我们绝对 超过了他们......这是一个非常好的开端。和他们的礼物相比, 我们的礼物给我们整个代表团都赢得了面 子。
} 
is the face of the group that was focused on. The delegates were delighted that their goal of enhancing the group's face had been achieved through the giving of a larger gift. At least one of them perceived it from a competitive point of view - that they had beaten the Americans by outdoing them in generosity. There can, of course, be multiple perspectives on perceptions of face in interaction: each party's views of their own face and the face of the other side, as well as each of their interpretations of what the other side thinks of themselves. In this case, it is questionable whether or not the Americans perceived it in this way.

A few days later, during their first meeting with a non-profit organization, another 'face incident' occurred from the perspective of the Chinese delegates. The interpreter, who had been hired by the American side, cut into the middle of the speaker's speech, saying: "Could you just finish the whole sentence? That is easier for me to translate." Then she turned to the Chinese delegates and in Chinese explained why she had interrupted the speaker. The American speaker seems to have found it face-threatening, in that the video data shows clearly that she blushed. However, would it also have been face-threatening to the Chinese? Nobody reacted at the time, but in the evening meeting the group revealed their feelings, displaying emotion-filled reactions to the incident. For example, two delegates commented as follows:

\section{Data extract 4: EM Comment}

D7: $\quad$... I noticed that at a certain point in the middle the interpreter interrupted the American speaker and asked her to finish the whole sentence. That was extremely face-losing for our Chinese side, because it seemed to be rashly requested by us. The speaker, like all her colleagues, looked very relaxed and tolerant, but I could still see that the color of her face changed on hearing the interpreter's forceful request. Yet the interpreter was arranged by the American side and we'd better not say anything.

D8: $\quad$ That's true. She was very impolite. We'd better not mention it to the American side and the interpreter. She will still be with us till City C... ${ }^{11}$

Here again we see that the delegates' concerns about face were not for the individuals per se but for 'the Chinese side'. They rated the incident as being 'extremely face-losing', because they thought the American participants might have regarded the interpreter's request as originating from the delegates. They were therefore dissatisfied with the interpreter, but they decided not to say anything to her about the matter, since she had been hired by the American hosts and any criticism of the interpreter could imply criticism of the hosts for not choosing a better interpreter. They did not want to risk making their hosts lose face and so they chose an avoidance strategy.

\subsection{Week 2: Ongoing gains and losses of face}

Near the beginning of Week 2, the delegation had a meeting with a federal government organization which had its offices in an historic building. After being warmly welcomed at the entrance and escorted inside by the American officials, the delegates entered the meeting room

\footnotetext{
${ }^{11}$ D7: 我......注意到, 中间某个时候, 翻译直接打断美方发言人, 要求她说完整的一句话。对于我们中 方来说, 好像是我们自己很鲁莽, 要求对方一句话一句话的说, 特别丢我们中方的脸。美方讲话的这个 人和她同事一样很放松、很宽容, 但是我仍然能看到她一听到翻译理直气壮的要求, 脸色还是变了, 但 是这个翻译是美方安排的, 我们也不好说什么。D8: 是啊, 她挺不礼貌的, 我们最好别跟美方和翻译提, 她会一直跟着我们到 C 城市。
} 
and were immediately amazed by the grandeur of the venue. They started taking photographs and this continued non-stop for five minutes. The American Research Director stood near the entrance of the majestic room, smiling in a friendly manner and waiting for them to finish their photographic spree. The HOD did not say anything at the time, but in the evening meeting he criticized them openly, because he believed that the delegation had lost some face during the episode.

\begin{abstract}
Data extract 5: EM Comment
I could understand the awe that everyone experienced. In addition, the other federal government organizations were not in recession and did not allow us to bring any cameras and video recorders, but taking photos continuously before the meeting started was not polite and lost a bit of our face. Fortunately the research director was patient enough to watch us taking photos for five minutes. I did not stop you because we had the interpreter employed by the Americans who could understand Chinese. I didn't want to make you lose face, and even more importantly, I didn't want to lose our delegation's face. Such behavior was detrimental to our delegation's image. We passed the security check smoothly. We were greeted by the American leaders in the hall, and escorted to the meeting room, which had increased our face, but then fifteen out of twenty of us took photos non-stop for five minutes [in front of the American side]. The increase in face was erased. We could have taken more photos after the meeting rather than letting the American officials wait for us. Everyone's behavior builds up our group image. Be mindful of your behavior all the time. ${ }^{12}$
\end{abstract}

Yet again we see the HOD's concern for the face of the group, and his belief that it is affected by the behavior of individual members. We also see the HOD's perceptions of the unfolding dynamics of face. He felt that they had initially gained face through being met near the entrance and through being escorted through the grand building, as this indicated the hosts were treating them as very important guests. However, he felt that this gain in face was then erased through the members' focus on taking photographs. The HOD implied that it was the delegates' insensitivity to the American hosts (making them wait too long) that was problematic, and that it was this lack of concern for the other that had made them lose face. However, the HOD did not want to say anything to them at the time, because the interpreter would have understood what he was saying. He felt that if she had heard him asking them to stop, this would have made them lose even more face. In actual fact, whether the American hosts were inconvenienced or not by the delegates' behavior, and whether they actually interpreted it negatively, is not clear. The American research director seemed to be happy with the officials' reactions, and it is even possible that it was face-enhancing for him in that he or his staff had chosen a venue that was impressive to the visitors. We cannot be sure about this, but nevertheless, as far as the delegation was concerned, it was a face loss.

A few days later, the delegation visited an influential professional association and further face sensitivities emerged. At the morning meeting, the HOD was not asked to give a return

\footnotetext{
12我能理解大家很震撼, 另外其它联邦政府机构不是休会期, 也不让带照相机和摄像机进去, 可是开会 以前一直拍照可不礼貌, 也有点丢脸, 所幸研究室主任很耐心, 等大家拍照拍完, 等了5分钟。我没阻 止大家是因为美方的翻译她听得懂中文, 我也不想驳大家的面子, 更重要的是我不想丢代表团的脸, 这 样的行为破坏了我们团的形象。我们顺利过了安检, 门口又有美方领导迎接, 送到会议室, 给我们长脸 了, 但是我们 20 个人里面 15 个人都拿出相机一个劲儿拍, 拍了 5 分钟, 也白长脸了。开完会以后再照也 来得及, 不要让对方等我们。每个人的行为加在一起, 就建立起来我们代表团的形象, 时刻注意自己的 行为举止。
} 
speech. However, when the American officials announced that the floor was open for questions, the HOD took the first turn to deliver a five-minute-long speech. The Americans' facial expressions betrayed their surprise and confusion at certain points, but they, too, did not comment on it. In the evening, the Chinese officials commended the HOD's move as a fight for face.

\section{Data extract 6: EM Comment}

D6: But the HOD did a very good job by making up for our return speech after the floor was open. This implied our firm position.

D14: Absolutely! The HOD’s move indicated our consciousness of this right and fought for our face. This was especially meaningful. ${ }^{13}$

Yet again we see the delegates' concern for their group face (referring to 'our face'). The implication is that if the HOD had not been able to give a return speech, this would have caused a loss of face for the delegation, because of the lack of equal opportunity for the American and Chinese sides each to give a speech (cf. Spencer-Oatey and Xing 2003, 2004, 2008). The failure to invite the HOD may have been face-threatening in itself. Here, however, the delegates focused on the HOD's success in 'fighting' for their face, ${ }^{14}$ and in a post-trip interview, one of the delegates commented that the HOD's efforts had successfully "maintained our face". ${ }^{15}$

\subsection{Week 3: Reflections on face achievements}

In the third week of the trip and towards the end of their visit, the delegation met with their counterpart organization. Once again gifts were exchanged, and the delegates were very proud of the items they had reserved for this particularly special occasion - a miniature of a terracotta warrior and a bronze antelope statue. In the evening, the DHOD made the following comments:

\section{Data extract 7: EM Comment}

Since it's really late now, I'll only say a few words about the gifts. We have given the best organizational gifts to Division A, our major host, and Division C of the United States Department of X, the final agency officially arranged by the US X Department for us. The terracotta warrior miniature and the (bronze) Tibetan antelope statue in the end were the highlight of our trip, elevating our face to a brand new height. It was a successful conclusion and the relationship between us was really good. The last was the best. It was an excellent ending. ${ }^{16}$

As can be seen from this comment, the DHOD felt the delegation had gained considerable face through giving these lavish gifts and was delighted about this. Shortly afterwards, the HOD reviewed their achievements over the whole of the trip and commented as follows:

\footnotetext{
${ }^{13}$ D6: 可是团长干得漂亮, 问答一开始, 就补上了我们的致辞, 显示了我们坚定的立场。D14: 就是, 团 长这么做, 就是说我们知道自己有什么权利, 也要争取面子, 特别有意义。

${ }^{14}$ While the HOD's behavior in this case can be seen as confrontational, the general strategy of the Chinese delegation was still avoiding and evading conflict, i.e. not to ask, comment or complain in the presence of Americans. This point will be taken up in Section 5.1.2.

15 保住了我们的面子。

${ }^{16}$ DHOD: 因为现在已经不早了, 就说几句礼物的事情。美国 X 部的 A 部门主要招待我们, C 部门是美 国 $\mathrm{X}$ 部给我们正式安排的最后一个拜访单位, 我们把送给单位最好的礼物给了他们。最后送得兵马俑和 藏羚羊雕像就是整个出访的亮点, 把我们的面子提升到了一个全新的高度, 收尾很成功, 我们之间的关 系也特别好, 最后的就是最好的, 结尾很漂亮。
} 


\section{Data extract 8: EM Comment}

HOD: In the past three weeks, we have gradually elevated our delegation's image through business activities day in and day out. The primary goal of developing good relations with the Americans has been basically achieved. We did not encounter many sensitive topics and you did a good job in defusing problematic situations by a nonconfrontational attitude. This has increased both our delegation's face and the Americans' face...

DHOD: As required by the HOD at the first meeting, every one of us has been contributing to elevating our delegation's face incessantly throughout this period. ${ }^{17}$

So despite the occasional instances of face loss, the delegation leaders' evaluations of overall achievement were positive. They concluded that the delegation, as well as the American hosts, had both gained face over the three week period, and that each of the delegates had played a role in achieving this. In other words, the goals that the leaders had set at the beginning of the trip were deemed to have been achieved successfully.

\section{Discussion}

\subsection{Participants' perspectives on face 5.1.1 The 'who' of face}

As can be seen from the data extracts in section 4, the Chinese participants' face concerns related primarily to the delegation as a group, lending support to the notion of group face which has been identified by a few researchers (e.g. He and Zhang, 2011; Ho, 1976; Nwoye, 1992; Spencer-Oatey and Xing, 2008). In our data, there were regular explicit mentions of the delegation's face (e.g. Data extracts 1, 2, 3, 5, 8), along with numerous references to 'we' and 'our face'. For example, in the HOD's arrival briefing, he exhorted them saying "We should not only increase our delegation's face but also our Ministry's face” (see Data extract 1 above), and from this we can see that in addition to the delegation's face he referred to the Chinese Ministry's face. There were also other occasional references to their Ministry's face in the evening meetings; for example, after an American host commented very positively on the gift of calligraphy the delegation had given him and had hung it up in his office, the DHOD commented in the evening meeting as follows: "When he put it in his office, it increased our delegation and our Ministry's face." 18

It is also apparent that the delegates saw their group face as being interconnected with the behavior of all the members. For example, in reviewing their achievements at the end of the trip, both the HOD and the DHOD referred to the impact of individual behavior on the face of the group (see Data extract 8), with the DHOD, for instance, saying "every one of us has been contributing to elevating our delegation's face”. Similarly, when the delegates spent a lot of

\footnotetext{
${ }^{17} \mathrm{HOD}$ : 过去三个礼拜, 我们通过每一天的公务活动, 周而复始, 逐渐提升了我们代表团的形象。首要 的目的是要和美方发展良好关系, 我们基本上都实现了。没有遇到很多敏感性话题, 在有问题的时候, 大家都是非对抗性的态度, 成功的解决了难题, 这既给我们代表团长了脸, 也给美方长了脸.......DHOD: 根据团长第一次开会时提出的要求, 我们每个人都很努力, 在整个出访过程中, 不断提升代表团的面子。 18 他一摆到办公室里, 也给我们代表团和我们部长了脸。
} 
time taking photographs (see Data extract 5 above), the HOD referred to the potential face loss of both the individual members and the group as a whole, saying "I didn't want to make you lose face, and even more importantly, I didn't want to lose our delegation’s face.”

These various participant perspectives suggest a number of points: a) that people can perceive group face to be of major significance in certain contexts; b) that individual behavior on behalf of a group (e.g. presenting a gift on behalf of a delegation) and personal individual behavior (e.g. asking an awkward question) can affect both group face as well as individual face; c) that the self/other distinction needs to be expanded to include own group/other group; and d) that since we may have membership of different nested groups (i.e. in this case study, each delegate was a member of the delegation; the delegation belonged to a particular Ministry; the Ministry formed part of the Chinese government; and the Chinese government belonged to the Chinese nation), the face of all these groups may potentially be affected.

\subsubsection{The strategic management of face and relations}

As is clear from the HOD's arrival briefing and pre-departure evaluation (Data extracts 1 and 8), key goals of the visit were to enhance the face of the delegation, the face of the Ministry they belonged to, and also the face of their American hosts. In order to help achieve these goals, members gave suggestions as to what they should or should not do under different circumstances. For instance, when they had given an inappropriate gift to an American host, one delegate commented "It was a little bit embarrassing. We should be $200 \%$ careful about gift preparation from now on" ; ${ }^{19}$ similarly, on another occasion when a gift was particularly well received, the DHOD noted that they should order more of those kinds of gifts for future overseas trips. This illustrates the close interconnection between face enhancement and face loss, and the often unpredictable and subjective nature of people's interpretations.

In communication terms, a preferred strategy of the group for managing face was verbal closedness; in other words, when they felt themselves to be in an uncertain or problematic situation, they tended not to ask, comment or complain about it. ${ }^{20}$ In fact, this is what their delegation leaders advised, as the following exhortation from the DHOD indicates:

\section{Data extract 9: EM comment}

When it comes to problematic situations, we should not speak or behave rashly. We'd better show that nothing is going wrong; otherwise it may embarrass both sides. We can discuss the reasons and solutions in our internal meetings afterwards. $^{21}$

This approach corresponds to Brown and Levinson’s (1987) “Don’t do the FTA” strategy.

The motivation for managing face strategically was a desire to build relations, in that the two elements are regularly juxtaposed in people's comments. For example, the HOD, immediately

\footnotetext{
19 有点虍尤尤。我们现在开始就要 $200 \%$ 的上心，准备礼物。

${ }^{20}$ It is worth mentioning here that while the Chinese delegation were generally inclined not to speak or behave rashly in problematic situations, and in private evening meetings they explicitly identified the strategy of verbal closedness in the presence of their intercultural interactants, there were exceptions. Extract 6 is a good example. The HOD actually took immediate action to deliver an uninvited five-minute-long return speech in an attempt to save face and 'turn around the situation'.

21 如果出现情况, 我们最好不要仓促说话或行事。我们要表现出一切正常, 要不双方都会䢟尤。大家之 后可以在内部会议中讨论分析, 解决问题。
} 
after talking about face enhancement in the arrival briefing, referred to the importance of developing good relations between their respective organizations. Similarly, the DHOD commented as follows at the end of the visit:

\section{Data extract 10: EM Comment}

As required by our HOD in the first meeting, every one of us has been contributing to elevating our delegation's face incessantly throughout this period. From official meetings to casual talk at the dinner table, we have continually increased our relations with the American side, contributing to a deeper relationship between the Chinese Ministry X and the United States Department of $\mathrm{X}^{22}$

This seems to support Haugh's (2012:116) claim that the primary engine of relational work in Chinese is relationships not face. In other words, building and managing relations is the principal goal and the effective handling of face is a component of that. In this case study, the daily comments about how their face was faring indicates that while a principal goal of the trip was promoting good relations (indicated by the very frequent mention of guanxi - see Table 1), the enhancement of the face of all concerned was regarded as an important element for achieving this. While there was natural concern to avoid losing face, a significant amount of attention was also directed at achieving gains in face. As noted in section 2 above, this face enhancement orientation is under-explored; most research and theorizing has focused on face threat and face loss. There is clearly a need for more research into face enhancement.

\subsubsection{The durability and quantification of face}

Recent theorizing about face has emphasized its interactional and emergent nature. For example, Haugh (2009:6) argues as follows:

... face is interactional in a number of different senses. In its most basic sense, face is interactional in that it presupposes evaluation by others of the behaviour of individuals as well as groups [...]. Without interaction there can be neither behaviour to evaluate nor others to make those evaluations. [...] Face is interactional in a more technical sense as well in that it emerges through interaction as a joint accomplishment of interlocutors [...]. In other words, we can say that face is co-constituted in interaction.

We fully acknowledge the interactional nature of facework; however, we would argue that it is also important to explore the face perceptions which extend beyond actual interactions, including the strategic planning of facework and reflections of ongoing gains and losses. The delegates in our case study clearly perceived the face of both the delegation and the Ministry as existing independently of (although naturally affected by) specific interactions. They spoke of their face rising and falling across the course of their interactions, treating it like an image that could be quantified. Face enhancement and loss were frequently spoken of in quantitative terms, with wordings such as "extremely face-losing" (Data extract 4), "lost a bit of our face" (Data extract 5) and "elevated our face to a brand new height" (Data extract 7). These ups and downs sometimes occurred over successive encounters. For instance, when the delegation visited a federal government organization in Week 2 (see Data Extract 5), the HOD spoke of the delegation's face being increased when they were escorted through the grand building, but

22根据团长第一次开会时提出的要求, 我们每个人都很努力, 在整个出访过程中, 不断提升代表团的面 子。从正式会谈到饭桌上的闲谈，大家都一直在增进和美方的关系，也加深了中美 X 部的关系。 
that increase was then erased when the members spent too long taking photographs. On other occasions, they spoke of their 'level' of face varying across a longer time span, such as a day (e.g. Data extract 3) or over several weeks. For example, at the end of the trip, the HOD made the following evaluation: "In the past three weeks, we have gradually elevated our delegation's image through business activities day in and day out” (see Data Extract 8).

The findings suggest that face is both ephemeral and enduring. While the interactional nature of facework can offer us valuable insights, the more enduring side of face perceptions which go beyond single interactions, also warrants further investigation. As face is both enduring and emergent (e.g. Ho, 1976, 1994; Lim 2009; Sifianou, 2011, 2013; Spencer-Oatey, 2007), we recommend that more studies of ongoing interaction are carried out so that this perspective can be explored more fully.

\subsection{Researching participant perspectives}

Haugh (2009:7) rightly points out that if face is treated as co-constituted in interaction, this raises a fundamental question: how can we decide whether a particular interaction has entailed face or facework in some way. This in turn brings another issue to the fore: the first-second order distinction. What are the relative strengths of analytic contributions of the participants' interpretations and those of the researchers/theorists? As Eelen (2001:253) points out, it is unwise to ignore the perspectives of the participants:

A situation in which the scientific account contradicts informants' claims and dismisses them as being 'wrong' does not represent a healthy situation. Such a practice immediately leads to a rupture between scientific and commonsense notions, causing the theory to lose its grasp on the object of analysis. In an investigation of everyday social reality informants can never be 'wrong', for the simple reason that it is their behaviour and notions we set out to examine in the first place.

In this study we have focused on the perspectives of the participants. Haugh (2009) explains two ways in which participant perspectives can be identified: through the use of conversation analysis to examine the participants' analyses of each other's verbal conduct and by conducting post-event interviews to ask them about it. Both of these approaches have strengths and weaknesses. In this case study we have used a third option that was fortuitously offered to us: participant reflections that were not elicited by the field researcher but were rather produced spontaneously in daily group internal evaluation meetings.

This, however, leads to a limitation of our study: that only the perspectives of the Chinese delegates were gathered systematically; those of the American participants were largely ignored. In fact, a limited amount of information was sought from the Americans through an open-ended questionnaire, but we were unable to collect detailed data. Nevertheless, the data we have indicates that interestingly different perspectives might emerge from different (groups of) participants if explored systematically. For example, in Week 1, during the same event as commented on in Data extract 4, the delegates starting discussing loudly among themselves something that the American speaker had said while answering a question. The interpreter explained to the American speaker why they were speaking so loudly and the next day the American speaker commented as follows in the open-ended questionnaire:

Data extract 11: Questionnaire comment 
I did feel slightly uncomfortable when the group began talking, rather loudly and in an animated manner, after some of my answers. It was explained to me that this was not meant as disrespectful so I was fine with it. [...] I take it as a compliment now that I know that my comments sparked debate and conversation amongst them and am not offended at all.

In contrast, however, to the American speaker's viewpoint, the delegates were annoyed with the interpreter, commenting in their evening meeting that the interpreter was condescending in explaining their behavior to the American speaker. In other words, the interpreter's explanation was perceived as face-threatening by the delegates but face-saving/enhancing by the American speaker. Different interpretations such as this are reminiscent of Spencer-Oatey and Xing's (2003, 2004, 2008) case study findings.

This urges us to pay close attention to what we mean when we say that face "emerges through interaction as a joint accomplishment of interlocutors" (Haugh, 2009:6). It does not necessarily mean that the evaluations need to be consistent across different individuals or different social groups. As Haugh (2012:122) further points out:

Participant understandings in this sense refers not to those evaluations or interpretations that can be explicitly agreed upon by participants, but rather to those evaluations of interpretations that are procedurally consequential in the course of interaction; in other words, participant understandings of face and im/politeness that are inferable from interactional conduct.

However, it can often be difficult to identify relationally consequential interpretations within the unfolding discourse, especially when an agreed strategy is to avoid disclosing either verbally or non-verbally any interactional discomfort (see Data extract 9).

\section{Conclusion}

In this paper we have examined the perspectives of a group of Chinese delegates on the gains and losses of face during a three-week official visit to the United States of America. Valuable insights into the delegates' interpretations of their intercultural interactions were obtained through analyzing their spontaneous comments, particularly in relation to their interactional goals and their evaluations of strategies for managing face. Notable features of their discussions were their emphasis on face enhancement and their treatment of face as a volatile yet durable image. We recommend, therefore, that future studies of face (a) move beyond the dominant focus on face threat and face saving, and (b) explore ways in which face endures across incidents and across time and contributes to the management of relations.

\section{Acknowledgements}

The Early Career Fellowship offered by the Institute of Advanced Study, University of Warwick gave the field researcher the opportunity to focus on the publication of this article. We would like to thank the anonymous reviewers for their valuable comments. 


\section{References}

Arundale, Robert B., 2006. Face as relational and interactional: a communication framework for research on face, facework, and politeness. Journal of Politeness Research 2 (2), 193-216.

Arundale, Robert B., 2010. Constituting face in conversation: face, facework, and interactional achievement. Journal of Pragmatics 42, 2078-2105.

Arundale, Robert B., 2013. Face as a research focus in interpersonal pragmatics: relational and emic perspectives. Journal of Pragmatics 58, 108-120.

Bargiela-Chiappini, Francesca, 2003. Face and politeness: new (insights) for old (concepts). Journal of Pragmatics 35 (10-11), 1453-1469.

Bousfield, Derek, 2008. Impoliteness in Interaction. John Benjamins, Amsterdam/Philadelphia.

Bousfield, Derek, Locher, Miriam, A., 2008. Impoliteness in Language: Studies on Its Interplay with Power in Theory and Practice. Mouton de Gruyter, Berlin/New York.

Bravo, Diana, 2008. (Im)politeness in Spanish-speaking socio-cultural contexts: introduction. Pragmatics 18 (4), 563-576.

Brown, Penelope, Levinson, Stephen, 1987. Politeness: Some Universals in Language Usage. Cambridge University Press, Cambridge. Originally published as 'Universals in language usage: Politeness phenomena’, in: Goody, E. (Ed.), (1978) Questions and Politeness: Strategies in Social Interaction. Cambridge University Press, Cambridge, pp. 56-311.

Chang, Wei-Lin Melody, Haugh, Michael, 2011. Evaluations of im/politeness of an intercultural apology. Intercultural Pragmatics 8 (3), 411-442.

Chen, Rong, 1993. Responding to compliments: a contrastive study of politeness strategies between American English and Chinese speakers. Journal of Pragmatics 20 (1), 49-75.

Chen, Rong, He, Lin, Hu, Chunmei, 2013. Chinese requests: in comparison to American and Japanese requests and with reference to the "East-West divide”. Journal of Pragmatics $55,140-161$.

Culpeper, Jonathan, 1996. Towards an anatomy of impoliteness. Journal of Pragmatics 25 (3), 349-367.

Culpeper, Jonathan, 2005. Impoliteness and entertainment in the television quiz show: The Weakest Link. Journal of Politeness Research, 1, 35-72.

Culpeper, Jonathan, 2008. Reflections on impoliteness, relational work and power. In: Bousfield, D., Locher, M.A. (Eds.), Impoliteness in Language: Studies on its Interplay with Power in Theory and Practice. Mouton de Gruyter, Berlin/New York, pp. 17-44.

Culpeper, Jonathan, 2011. Impoliteness: Using Language to Cause Offence. Cambridge University Press, Cambridge.

Culpeper, Jonathan, 2012. (Im)politeness: three issues. Journal of Pragmatics 44 (9), 11281133.

Culpeper, Jonathan, Bousfield, Derek, Wichmann, Anne, 2003. Impoliteness revisited: with special reference to dynamic and prosodic aspects. Journal of Pragmatics 35 (10-11), 1545-1579.

Culpeper, Jonathan, Marti, Leyla, Mei, Meilian, Nevala, Minna, Schauer, Gila, 2010. Crosscultural variation in the perception of impoliteness: a study of impoliteness events reported by students in England, China, Finland, Germany, and Turkey. Intercultural Pragmatics 7 (4), 597-624.

Dominici, Kathy, Littlejohn, Stephen W., 2006. Facework. Bridging Theory and Practice. Thousand Oaks, Sage.

Eelen, Gino, 2001. A Critique of Politeness Theories. St. Jerome, Manchester. 
Gao, Ge, 2009. Face and self in Chinese communication. In: Bargiela-Chiappini, F., Haugh, M. (Eds.), Face, Communication and Social Interaction. Equinox, London, pp. 175191.

Garcés-Conejos Blitvich, Pilar (2013) Face, identity, and im/politeness: Looking backwards, moving forward-from Goffman to Practice Theory. Journal of Politeness Research, 9, 1-33.

Goffman, Erving, 1959. The Presentation of Self in Everyday Life. Doubleday, New York.

Goffman, Erving, 1967. On face-work: an analysis of ritual elements in social interaction. In: Goffman, E., Interaction Ritual: Essays on Face-to-Face Behavior. Doubleday, New York, pp. 5-45.

Grainger, Karen, Mills, Sara, Sibanda, Mandla, 2010. "Just tell us what to do": Southern African face and its relevance to intercultural communication. Journal of Pragmatics 42 (8), 2158-2171.

Hammersley, Martyn, Atkinson, Paul, 2007. Ethnography: Principles in Practice ( ${ }^{\text {rd }}$ ed.). Routledge, London.

Haugh, Michael, 2009. Face and interaction. In: Bargiela-Chiappini, F., Haugh, M. (Eds.), Face, Communication and Social Interaction. Equinox, London, pp. 1-30.

Haugh, Michael, 2010. Jocular mockery, (dis)affiliation, and face. Journal of Pragmatics 42 (8), 2106-2119.

Haugh, Michael, 2012. Epilogue: the first-second order distinction in face and politeness research. Journal of Politeness Research 8 (1), 111-134.

Haugh, Michael, 2013. Disentangling face, facework and im/politeness. Sociocultural Pragmatics 1 (1), 46-73.

Haugh, Michael, Bargiela-Chiappini, Francesca, 2010. Face in interaction. Journal of Pragmatics 42 (8), 2073-2077.

Haugh, Michael, Hinze, Carl, 2003. A metalinguistic approach to deconstructing the concepts of 'face' and 'politeness' in Chinese, English and Japanese. Journal of Pragmatics 35 (10-11), 1581-1611.

Haugh, Michael, Watanabe, Yasuhisa, 2009. Analysing Japanese ‘face-in-interaction’: insights from intercultural business meetings. In: Bargiela-Chiappini, F., Haugh, M. (Eds.), Face, Communication and Social Interaction. Equinox, London, pp. 78-95.

He, Ming, Zhang, Shao-jie, 2011. Re-conceptualizing the Chinese concept of face from a facesensitive perspective: a case study of a modern Chinese TV drama. Journal of Pragmatics 43 (9), 2360-2372.

Hernández-Flores, Nieves, 2004. Politeness as face enhancement: an analysis of Spanish conversations between friends and family. In: Márquez-Reiter, R., Placencia, M. E. (Eds.), Current Trends in the Pragmatics of Spanish. John Benjamins, Amsterdam/Philadephia, pp. 265-284.

Hernández-Flores, Nieves, 2008. Politeness and other types of facework: communicative and social meaning in a television panel discussion. Pragmatics 18 (4), 681-706.

Hinze, Carl, 2012. Chinese politeness is not about 'face': evidence from the business world. Journal of Politeness Research 8 (1), 11-27.

Ho, David, 1976. On the concept of face. American Journal of Sociology 81, 867-884.

Ho, David, 1994. Face dynamics: from conceptualization to measurement. In: Ting-Toomey, S. (Ed.), The Challenge of Facework. State University of New York Press, Albany, New York, pp. 269-286.

Hopf, Christel, 2004. Qualitative interviews: an overview. In: Flick, U., Kardorff, E. v., Steinke, I. (Eds.), A Companion to Qualitative Research. Sage, London, pp. 203-208.

Hsun, Lu, 1960. On 'face'. In: Yang, H-y., Yang, G. (Trans. and eds.), Selected Stories of Lu Hsun, Foreign Language Press, Beijing, vol. 4, pp.129-132. 
Hu, Hsien Chin, 1944. The Chinese concepts of "face". American Anthropologist 41 (1), 4554.

Kádár, Dániel, Haugh, Michael, 2013. Understanding Politeness. Cambridge: Cambridge University Press.

Leech, Geoffrey, 1983. Principles of Pragmatics, Longman, London.

Li, Julie Juan, Su, Chentin, 2007. How face influences consumption. International Journal of Market Research 49 (2), 237-56.

Lim, Tae-Seop, 2009. Face in the holistic and relativistic society. In: Bargiela-Chiappini, F., Haugh, M. (Eds.), Face, Communication and Social Interaction. Equinox, London, pp. 250-268.

Lin, Yutang, 1935. My Country and My people, Halcyon House, New York.

Morisaki, Seiichi, Gudykunst, William, B., 1994. Face in Japan and the United States. In: TingToomey, S. (Ed.), The Challenge of Facework. State University of New York Press, Albany, New York, pp. 47-94.

Nida, Eugene, Taber, Charles, 1969. The Theory and Practice of Translation. Leiden: Brill.

Nwoye, Onuigbo, G., 1992. Linguistic politeness and socio-cultural variations of the notion of face. Journal of Pragmatics 18 (4), 309-328.

Qian, Wang, Razzaque, Mohammed A., Kau, Ah-Keng, 2007. Chinese cultural values and giftgiving behavior. Journal of Consumer Marketing 24 (4), 214-228.

Ruhi, Şükriye, Işık-Güler, Hale, 2007. Conceptualizing face and relational work in (im)politeness: revelations from politeness lexemes and idioms in Turkish. Journal of Pragmatics 39 (4), 681-711.

Schegloff, Emanuel A., 1991. Reflections on talk and social structure. In: Boden, D., Zimmerman, D. H. (Eds.), Talk and Social Structure. Polity Press, Oxford, pp. 44-70.

Seligman, Scott D., 1999. Guanxi: grease for the wheels of China. China Business Review 26 (5), 34-38.

Sifianou, Maria, 2011. On the concept of face and politeness. In: Bargiela-Chiappini, F., Kádár, D.Z. (Eds.), Politeness across Cultures. Palgrave Macmillan, Basingstoke, pp. 42-58.

Sifianou, Maria, 2013. On culture, face and politeness. Again. Paper presented at the cc2013Face Communication across Cultures: Face and Interaction, University of Silesia, Sosnowiec, Poland.

Spencer-Oatey, Helen, 2007. Theories of identity and the analysis of face. Journal of Pragmatics 39 (4), 639-656.

Spencer-Oatey, Helen, 2008. Rapport Management: A framework for analysis. In: SpencerOatey, H. (Ed.), Culturally Speaking: Culture, Communication and Politeness Theory ( $2^{\text {nd }}$ ed.). Continuum, London, pp. 2-47.

Spencer-Oatey, Helen, Xing, Jianyu, 2003. Managing rapport in intercultural business interactions: a comparison of two Chinese-British business meetings. Journal of Intercultural Studies 24 (1), 33-46.

Spencer-Oatey, Helen, Xing, Jianyu, 2004. Rapport management problems in Chinese-British business interactions: a case study. In House, J., Rehbein, J. (Eds.), Multilingual Communication. John Benjamins, Amsterdam/Philadephia, pp.197-222.

Spencer-Oatey, Helen, Xing, Jianyu, 2008. Issues of face in a Chinese business visit to Britain. In: Spencer-Oatey, H. (Ed.), Culturally Speaking: Culture, Communication and Politeness Theory ( $2^{\text {nd }}$ ed.), Continuum, London, pp. 258-273.

St. André, James, 2013. How the Chinese lost 'face'. Journal of Pragmatics 55, 68-85.

Terkourafi, Marina. Toward a universal notion of face for a universal notion of co-operation. In: Kecskes, I., Horn, L. (Eds.), Explorations in Pragmatics: Linguistic, Cognitive and Intercultural Aspects. Mouton de Gruyter, Berlin/New York, pp. 313-344. 
Ting-Toomey, Stella, 2009. Facework collision in intercultural communication. In: BargielaChiappini, F., Haugh, M. (Eds.), Face, Communication and Social Interaction. Equinox, London, pp. 227-249.

Ting-Toomey, Stella, Kurogi, Atsuko, 1998. Facework competence in intercultural conflict: An updated face-negotiation theory. International Journal of Intercultural Relations 22 (2), 187-225.

Tracy, Karen, 2008. "Reasonable hostility”: situation-appropriate face-attack. Journal of Politeness Research 4 (2), 169-191.

Watts, Richard J, 2005. Linguistic politeness research. Quo vadis? In: Watts, RJ., Ide, S. \& Ehlich, K. (Eds.), Politeness in Language: Studies in Its History, Theory and Practice ( $2^{\text {nd }}$ ed.), Mouton de Gruyter, Berlin/New York, pp. xi-xivii.

Yan, Yunxiang, 1996. The Flow of Gifts: Reciprocity and Social Networks in a Chinese Village. Stanford University Press, Palo Alto, CA.

Yang, M. M.-H., 1994. Gifts, Favors, and Banquets: The Art of Social Relationships in China. Cornell University Press, Ithaca. 
APPENDIX

\section{Key post-trip interview questions}

1. What impressed you the most in the trip?

此次出访给你留下印象最深的是什么事情?

2. What were the biggest challenges to intercultural meetings? How to overcome them? 会谈中最大的挑战有哪些？如何克服？

3. What were you dissatisfied about the intercultural meetings? 会谈中你有哪些感觉不太满意的地方？

4. Did institutional or/and cultural differences have an impact on communication? 体制、文化差异对沟通有影响吗？

5. What was your impression of American officials before the trip? What is your impression after this trip? Are there any changes?

出访前, 对美国官员印象如何? 出访后, 印象如何? 发生了什么变化?

6. What is a qualified interpreter?

什么样的翻译才合格? 